\title{
SPECIFIC OPERATIONS FOR ACCOUNTS' HOMOGENIZATION WITH A VIEW TO CONSOLIDATION
}

\author{
Mihai Deju \\ "Vasile Alecsandri" University of Bacau \\ mihai.deju@ub.ro
}

\begin{abstract}
The preparation of annual consolidated financial statements by group companies represents a relatively new problematic issue for regulating bodies, the world of the academia, as well as for accounting practitioners. The current national and international accounting standards undergo a continuous change and updating to the economic and judicial reality of the business environment which, in turn, goes through a permanent transformation because of the globalization of national economies. These novelties raise the necessity of debates organized by accounting specialists with the aim of finding solutions that respect legal regulations related to the preparation of financial statements for consolidation. The present article approaches accounting aspects related to the operation of adjusting individual financial statements that are the object of consolidation.
\end{abstract}

\section{Keywords}

amortization/depreciation; accounts' homogenization; different accounting policies

\section{JEL Classification \\ M41}

Accounting standards regarding the preparation of annual consolidated financial statements ${ }^{1}$ stipulate a series of rules concerning the homogenization of the financial statements of the entities that are to be consolidated, as follows:

a) when an entity included in the consolidation perimeter/scope (group member) employs, for similar transactions and events under similar circumstances, other accounting policies than those adopted in the case of annual consolidated financial statements, in order to ensure conformity to the group accounting policies, before being included in the consolidated financial statements, the individual financial statements of the respective entity must be adjusted in the corresponding manner;

b) the entity that prepares the annual consolidated financial statements must apply the same evaluation methods as in the case of its own annual financial statements, which means that the assets and the liabilities of the entities included in the consolidation perimeter/scope will be evaluated by means of the same methods when they are included in the annual consolidated financial statements, methods which the

\footnotetext{
${ }^{1}$ Accounting Standards regarding annual individual financial statements and annual consolidated financial statements, approved by OMPF no. 802 dated December 29 2014, published in the Official Gazette of Romania, no. 963 dated December 30 2014, part 8.6, pos.517-522.

* Consolidation can also be carried out on the basis of cash flows (see Marian Săcărin, "Contabilitate aprofundată"- par. Consolidation Modes, p. 228).
} 
entity that prepares consolidated financial statements also uses for drawing up its own annual financial statements, respectively its annual consolidated financial statements;

c) în the case of assets which were adjusted to fair market value, only for fiscal purposes, the annual consolidated financial statements will include them only after eliminating the respective adjustments.

We can thus conclude that the annual individual financial statements of the entities included in the consolidation perimeter/scope, i.e. subsidiaries, associated entities or entities over which common control is exercised and which use evaluation methods or accounting policies that differ from those applied when drawing up annual consolidated financial statements, must be restated (adjusted) obligatorily and waivers from this requirement are accepted only in exceptional cases. Possible waivers or exceptions are presented and justified in explanatory notes for annual consolidated financial statements.

In the case of consolidation on the basis of accounts aggregation*, adjustments are made both for the differences corresponding to the current financial year and for the differences corresponding to the previous financial years, with the mentioning that the adjustments corresponding to the previous financial years affect equities (reported result, reserves, etc.) and the adjustments corresponding to the current financial year affect its financial result.

The operations regarding the adjustments that occur when including the financial statements in the consolidated accounts of the entities that are part of the consolidation scope involve accounting reasoning that practitioners should perform with significant judgment and professional competence.

We will further present the accounting treatment corresponding to the various types of adjustments (restatements) occurring as a result of different amortization or depreciation policies.

A. Company "B" purchased on the $25^{\text {th }}$ of December 2010 a vehicle that cost 160,000 lei. According to the company's depreciation policy, the firm will depreciate the respective fixed asset in a straight line manner, over a period of five years.

Starting with the $1^{\text {st }}$ of January 2013 , company "B" becomes a subsidiary of company "A", with the latter having the intention to include the former in the scope of consolidation.

Company "A" (the parent company), according to its own policies regarding the depreciation of tangible fixed assets, has its own rule concerning the same category of fixed assets, respectively a working period of 8 years and a straight line depreciation type.

Given the different depreciation policies used by the parent company and its subsidiary for similar tangible fixed assets, at the time of the consolidation, company "A" will start adjusting (restating) the annual consolidated financial statements prepared by company "B" (subsidiary) in compliance with the Accounting standards regarding consolidated financial statements in effect, which were previously mentioned.

The differences between the depreciation calculated according to the accounting policies of the parent company and the depreciation calculated by the subsidiary in line with its own accounting policies used for preparing annual consolidated financial statements, are presented as follows: 


\begin{tabular}{|c|c|c|c|c|c|c|c|c|}
\hline \multirow[t]{2}{*}{$\begin{array}{l}\mathrm{N} \\
\mathrm{o} .\end{array}$} & \multirow[t]{2}{*}{$\begin{array}{l}\text { Financ } \\
\text { ial } \\
\text { year }\end{array}$} & \multicolumn{2}{|c|}{$\begin{array}{l}\text { Depreciation } \\
\text { calculated } \\
\text { company } \\
\text { (consolidating } \\
\text { parent) }\end{array}$} & \multicolumn{2}{|c|}{$\begin{array}{l}\text { Depreciation } \\
\text { calculated } \\
\text { company "B" - } \\
\text { subsidiary }\end{array}$} & \multicolumn{3}{|c|}{ Differences of depreciation ${ }^{*}$} \\
\hline & & annual & $\begin{array}{l}\text { accumul } \\
\text { ated }\end{array}$ & annual & $\begin{array}{l}\text { accumul } \\
\text { ated }\end{array}$ & annual & $\begin{array}{l}\text { precedin } \\
\mathrm{g}\end{array}$ & $\begin{array}{l}\text { accumul } \\
\text { ated }\end{array}$ \\
\hline 1 & 2011 & 20,000 & 20,000 & 32,000 & 32,000 & $-12,000$ & - & $-12,000$ \\
\hline 2 & 2012 & 20,000 & 40,000 & 32,000 & 64,000 & $-12,000$ & $-12,000$ & $-24,000$ \\
\hline 3 & 2013 & 20,000 & 60,000 & 32,000 & 96,000 & $-12,000$ & $-24,000$ & $-36,000$ \\
\hline 4 & 2014 & 20,000 & 80,000 & 32,000 & 128,000 & $-12,000$ & $-36,000$ & $-48,000$ \\
\hline 5 & 2015 & 20,000 & 100,000 & 32,000 & 160,000 & $-12,000$ & $-48,000$ & $-60,000$ \\
\hline 6 & 2016 & 20,000 & 120,000 & - & 160,000 & 20,000 & $-60,000$ & $-40,000$ \\
\hline 7 & 2017 & 20,000 & 140,000 & - & 160,000 & 20,000 & $-40,000$ & $-20,000$ \\
\hline 8 & 2018 & 20,000 & 160,000 & - & 160,000 & 20,000 & $-20,000$ & - \\
\hline
\end{tabular}

*Note: The differences of depreciation (annual and cumulated) are calculated between the (annual and cumulated) depreciation determined in compliance with the accounting policies of the parent company and the depreciation calculated by the consolidated company (company " $\mathrm{B}$ ", the subsidiary).

The accounting treatment regarding the restatement of differences between the depreciation calculated in compliance with the policies of the parent company and the depreciation calculated by its subsidiary, at the time of the consolidation, is the following:

1. In the first year of consolidation, i.e. in 2013, the difference of depreciation corresponding to the current year $(-12,000$ lei) will be recorded as depreciation reduction, on the basis of the current result by means of depreciation expenses, and the preceding differences of depreciation (corresponding to 2011 and 2012) will influence equities (retained earnings/reserves), as follows:

\begin{tabular}{ccc}
\hline $\mathbf{2 8 1 4}$ & $\%$ & 36,000 \\
"Depreciation of other & $\mathbf{6 8 1 1}$ & 12,000 \\
tangible fixed assets" & "Operating expenses related to the \\
depreciation of fixed assets" & $\mathbf{1 0 6}$ & \\
& "Reserves & 24,000 \\
\hline
\end{tabular}

In the financial years 2014 and 2015 the accounting rationale is the same, hence:

2. In the financial year 2014:

\section{$\mathbf{2 8 1 4}=$}

"Depreciation of other

tangible fixed assets"

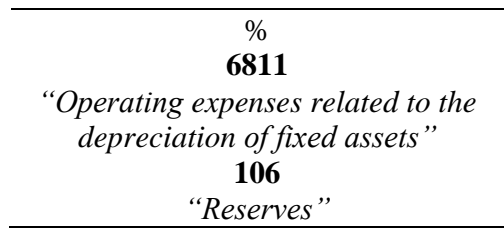

"Reserves"
48,000

36,000

60,000

"Operating expenses related to the depreciation of fixed assets"

106

"Reserves" 
4. In the financial year 2016, in the accounting records of the subsidiary, the vehicle is entirely depreciated. In the consolidated accounts there should be recorded, for the current period, a supplement for expenses with depreciation corresponding to the annual depreciation quota established in compliance with the policies of the parent company $(+20,000$ lei) and there should be adjusted the depreciation calculated in excess of what is due in previous financial years for the sum of 60,000 lei, as follows:

$\begin{gathered}\mathbf{6 8 1 1} \\ \frac{\text { "Operating expenses related to }_{\text {the depreciation of fixed assets" }}}{\text { 2814 }}\end{gathered}=$

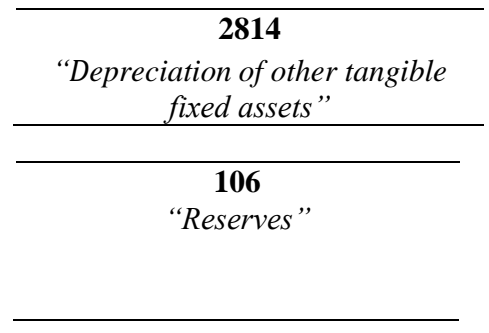

20,000

5. The same restatement entries shall be recorded in the subsequent financial years (2017 and 2018), until the vehicle shall be entirely depreciated in agreement with the accounting policies of the parent company:

\begin{tabular}{|c|c|c|c|}
\hline - in 2017 & & & \\
\hline $\begin{array}{c}\mathbf{6 8 1 1} \\
\text { "Operating expenses related to } \\
\text { the depreciation of fixed assets" }\end{array}$ & $=$ & $\begin{array}{c}\mathbf{2 8 1 4} \\
\text { "Depreciation of other tangible } \\
\text { fixed assets" }\end{array}$ & 20,000 \\
\hline $\begin{array}{c}\mathbf{2 8 1 4} \\
\text { "Depreciation of other } \\
\text { tangible fixed assets" }\end{array}$ & $=$ & $\begin{array}{c}\mathbf{1 0 6} \\
\text { "Reserves" }\end{array}$ & 40,000 \\
\hline - in 2018 & & & \\
\hline $\begin{array}{c}\mathbf{6 8 1 1} \\
\text { "Operating expenses related to } \\
\text { the depreciation of fixed assets" }\end{array}$ & $=$ & $\begin{array}{l}\mathbf{2 8 1 4} \\
\text { "Depreciation of other } \\
\text { tangible fixed assets" }\end{array}$ & 20,000 \\
\hline $\begin{array}{c}\mathbf{2 8 1 4} \\
\text { "Depreciation of other } \\
\text { tangible fixed assets" }\end{array}$ & $=$ & $\begin{array}{c}106 \\
\text { "Reserves" }\end{array}$ & 20,000 \\
\hline
\end{tabular}

B. At the end of the financial year N, company A, a subsidiary of company B, purchases a tangible fixed asset which is worth 150,000 lei. In the individual accounts of the subsidiary, it is depreciated in a straight line manner, over a period of ten years, whereas the accounting policies of company B also stipulate a straight line depreciation but over a period of six years. At the end of the financial year $\mathrm{N}+3$, the fixed asset is sold at a price of 125,000 lei.

Differences of depreciation, resulting after the subsidiary company applies different accounting policies for similar transactions and events under similar circumstances, corresponding to the three financial years, are as follows: 


\begin{tabular}{|c|c|r|r|r|r|r|}
\hline $\begin{array}{l}\text { Financial } \\
\text { year }\end{array}$ & $\begin{array}{c}\text { Depreciation calculated } \\
\text { in compliance with the } \\
\text { accounting policies of } \\
\text { the parent company }\end{array}$ & $\begin{array}{c}\text { Depreciation calculated } \\
\text { in compliance with the } \\
\text { accounting policies of } \\
\text { the subsidiary }\end{array}$ & \multicolumn{2}{|c|}{ Difference } \\
\cline { 2 - 8 } & annual & accumulated & annual & accumulated & current & accumulated \\
\hline $\mathrm{N}+1$ & 25,000 & 25,000 & 15,000 & 15,000 & 10,000 & 10,000 \\
\hline $\mathrm{N}+2$ & 25,000 & 50,000 & 15,000 & 30,000 & 10,000 & 20,000 \\
\hline $\mathrm{N}+3$ & 25,000 & 75,000 & 15,000 & 45,000 & 10,000 & 30,000 \\
\hline
\end{tabular}

Company B will adjust the annual financial statements of subsidiary company A when preparing the annual consolidated financial statements, as shown below:

\section{Adjustment of the financial statements of the subsidiary company:}

a) In the financial year $\mathrm{N}+1$

In this financial year, the depreciation of 15,000 lei recorded by the subsidiary shall be increased with the sum of 10,000 lei. After the increase of the Depreciation, the net value of the tangible fixed asset in the consolidated financial statements is of 125,000 lei, whereas in the individual financial statements of the subsidiary it has a value of 135,000 lei.

The accounting recording corresponding to the adjustment is as follows:

$\mathbf{6 8 1 1}$
"Operating expenses related to
the depreciation of fixed assets"

$\mathbf{2 8 1}$
"Depreciation of tangible fixed
assets"

In the financial years $\mathrm{N}+2$ and $\mathrm{N}+3$, besides supplementing the expenses with the depreciation corresponding to the current financial year, the differences of depreciation corresponding to the previous financial years will also be adjusted, as follows:

b) In the financial year $\mathrm{N}+2$ :

\begin{tabular}{c}
$\mathbf{\%}$ \\
$\mathbf{6 8 1 1}$ \\
"Operating expenses related to \\
the depreciation of fixed assets" \\
$\mathbf{1 0 6}$ \\
"Reserves" $F$ \\
\hline
\end{tabular}

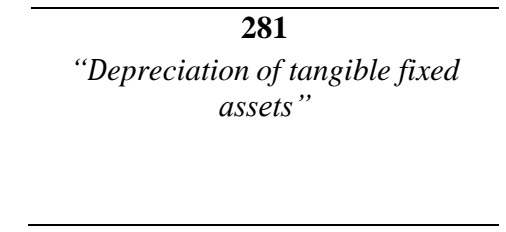

c) In the financial year $\mathrm{N}+3$

\begin{tabular}{c}
$\mathbf{\%}$ \\
$\mathbf{6 8 1 1}$ \\
"Operating expenses related to \\
the depreciation of fixed assets" \\
$\mathbf{1 0 6}$ \\
"Reserves" $F$ \\
\hline
\end{tabular}

\begin{tabular}{c}
$\mathbf{2 8 1}$ \\
"Depreciation of tangible fixed \\
assets" \\
\hline
\end{tabular}

As a result of the fixed asset's sale by the subsidiary, at the end of the financial year $\mathrm{N}+2$, its financial result shall be restated as follows:

a) The financial result corresponding to the fixed asset's sale operation, as it is recorded in the books and financial statements of the subsidiary is shown below:

\begin{tabular}{|l|r|}
\hline Revenues from sale of fixed assets (7583) & 125,000 \\
\hline Accounting value of fixed assets (212) & 150,000 \\
\hline
\end{tabular}




\begin{tabular}{|l|r|}
\hline Accumulated depreciation at the time of sale & 45,000 \\
\hline Net book value (unamortized value 6583) & 105,000 \\
\hline Result obtained after sale of fixed asset & 20,000 \\
\hline
\end{tabular}

b) The financial result, in line with the accounting depreciation policy of the company that prepares consolidated financial statements (parent company B), obtained from sale of the fixed asset by the subsidiary:

\begin{tabular}{|l|r|}
\hline Revenues from sale of fixed assets (7583) & 125,000 \\
\hline Accounting value of fixed assets (212) & 150,000 \\
\hline Accumulated depreciation at the time of sale & 75,000 \\
\hline Net book value (unamortized value 6583) & 75,000 \\
\hline Result obtained after sale of fixed asset & 50,000 \\
\hline
\end{tabular}

The financial result reported in the subsidiary's financial statements (which are the object of the consolidation) shall have to be increased with the difference of 30.000 lei by deducing the expenses with the disposed assets, because the subsidiary recorded an unamortized value corresponding to the sold tangible asset of 105,000 lei as compared to 75,000 lei, which should have been the value recorded in agreement with the depreciation policy applied by the parent company. Accounting entries of the financial result adjustment in the financial statements of the subsidiary are as follows:

$\mathbf{2 8 1}$
"Depreciation of tangible fixed
assets"

$\mathbf{6 5 8 3}$
"Operating expenses related
to disposed assets"

C. Subsidiary company "A" recorded as intangible fixed assets, at the beginning of the financial year $\mathrm{N}$, set-up costs/expenses of 60,000 lei. These expenses have to be amortized in a straight-line rate, over three years. However, in the consolidated accounts, the set-up costs are recorded as expenses of the financial year when they were spent. The entity that performs the consolidation shall have to adjust the financial statements of the subsidiary A, as follows:

\section{a) In the financial year $\mathrm{N}$ :}

Because in the case of the company that prepares the annual consolidated financial statements the set-up costs/expenses are not capitalized, the consequences of their capitalization by the subsidiary will be eliminated:

$\frac{\mathbf{2 8 0 1}}{\text { “Amortization of set-up expenses" }}=$

\begin{tabular}{c}
$\mathbf{6 8 1 1}$ \\
"Operating expenses related \\
to the amortization of fixed \\
assets" \\
\hline $\mathbf{2 0 1}$ \\
"Set-up expenses"
\end{tabular}

* Set-up expenses shall be recorded here, in agreement with their economic nature (charges, taxes corresponding to the services of registering the company at the Registry of Commerce, advertising etc.) 
b) In the financial year $\mathbf{N}+\mathbf{1}$, according to the accounting rationale, adjustments will be made both for the differences corresponding to the current year and for the amortization difference corresponding to the previous year.

\begin{tabular}{ccc}
\hline $\mathbf{2 8 0 1}$ & $=$ & $\mathbf{1 0 6}$ \\
\hline $\begin{array}{c}\text { "Amortization of set-up costs" } \\
\text { "Amortization of set-up costs" }\end{array}$ & $=$ & \begin{tabular}{c} 
"Reserves" \\
\hline
\end{tabular} \\
$\begin{array}{c}\text { "Operating expenses related } \\
\text { to the amortization of fixed } \\
\text { assets" }\end{array}$ \\
\hline
\end{tabular}

c) In the financial year $\mathbf{N}+\mathbf{2}$ - (the last year of amortization) the accounting rationale is similar to the one corresponding to financial year $\mathrm{N}+1$, as shown below:

\begin{tabular}{ccc}
\hline $\mathbf{2 8 0 1}$ & $\mathbf{\%}$ & 60,000 \\
"Amortization of set-up costs" & $\mathbf{6 8 1 1}$ & 20,000 \\
& "Operating expenses related \\
to the amortization of fixed & \\
& assets" & 40,000 \\
& $\mathbf{1 0 6}$ & \\
\hline
\end{tabular}

\section{Conclusions}

As it can be concluded from the contents of the approached theme, accounting standards specific to the consolidation of financial statements by group companies represent for specialists, both theoreticians and practitioners in the field of accounting, an issue undergoing full dynamic and which requires permanent debate with a view to finding the most adequate implementation solutions. The adjustment of the individual financial statements of companies included in the consolidation scope (subsidiaries, associated entities or entities controlled in common) and which "employ different accounting policies for similar transactions and events under similar circumstances" represents a compulsory requirement that needs to be put into practice by accountants. In this context, regulating or normative institutions from the field of accounting, professional associations and the academia should offer models and solutions for solving practical situations that require conformity to the group's accounting policies.

\section{References}

Accounting Law no.82/91 republished in the Official Gazette of Romania no. 454/2008, with subsequent amendments and additions.

Companies Law, no. 31/90 republished in the Official Gazette of Romania, Part I, no. 1066 dated 17 November 2004 with subsequent amendments and additions.

Deju Mihai (2013), Contabilitate aprofundată-curs universitar, Alma Mater, Bacău.

OMPF no. 1802 dated 29 December 2014 for the approval of Accounting Standards concerning annual individual financial statements and annual consolidated financial statements, published in the Official Gazette of Romania, no. 963/ dated 30 December 2014, with subsequent amendments and additions.

OMPF no. 897/2015 for the approval of Methodological norms concerning the reflection in accounting of the main operations of merger, partition, dissolution 
and liquidation of companies as well as of the withdrawal or exclusion of certain associates from companies, with subsequent amendments and additions. 